\title{
Peningkatan Nilai Tambah Produk Olahan Dendeng Daging Kerbau Fermentasi Melalui Inovasi Kemasan di Desa Pernek Kecamatan Moyo Hulu
}

\author{
Ihlana Nairfana ${ }^{1}$, Chairul Anam Afgani ${ }^{1}$, Imam Munandar ${ }^{2}$ \\ ${ }^{\text {I}}$ Program Studi Teknologi Hasil Pertanian, Universitas Teknologi Sumbawa, Kabupaten Sumbawa, Nusa Tenggara Barat, \\ Indonesia \\ ${ }^{2}$ Program Studi Peternakan, Universitas Teknologi Sumbawa, Kabupaten Sumbawa, Nusa Tenggara Barat, Indonesia
}

\section{Article history}

Received: 8 Juni 2021

Revised: 10 Juni 2021

Accepted: 22 Juni 2021

*Corresponding Author: Ihlana Nairfana1, Program Studi Teknologi Hasil Pertanian, Universitas Teknologi Sumbawa, Kabupaten Sumbawa, Nusa Tenggara Barat, Indonesia Email:

ihlana.nairfana@uts.ac.id

\begin{abstract}
Moyo Hulu is one of the sub-districts in Sumbawa Regency which has a hilly area and has a fairly large proportion of state forest and dry land. Many local farmers have used buffalo to plow the fields. When the buffalo is old, the buffalo will be slaughtered for meat. Buffalo meat is a potential source of nutrition, because of its high protein content, low water content, and higher myoglobin than beef. Local residents of Pernek Village have been processing buffalo meat into traditional flavored jerky, but it has never been packaged properly. In addition, the jerky produced is half-cooked beef jerky with a hard texture. Cooking methods and inappropriate temperatures will result in low quality jerky with a very hard texture, therefore ready-to-eat jerky is one of the innovations to make beef jerky easier to process and maintain its nutritional content. There are many processing techniques available to increase the tenderness of buffalo meat; One well -known technique is fermentation with lactic acid bacteria $(B A L)$. The aim of this program is to increase the added value of buffalo jerky through processing and packaging innovation. The method used is socialization, counseling, as well as training and mentoring. Furthermore, the implementation of the socialization event took place at the Pernek Village Office which was attended by Pernek's villagers, while this activity is followed by parties from the village such as Village-Owned Enterprises (BUMDes) and village officials. Through this program, it is hoped that the community is able to increase the added value of processed buffalo jerky through processing and packaging innovation.
\end{abstract}

Keywords: buffalo jerky, Pernek, Fermentasi, Pengemasan

Abstrak: Moyo Hulu adalah salah satu kecamatan di Kabupaten Sumbawa yang memiliki daerah berbukit dan memiliki hutan dan tanah kering yang cukup besar. Mayoritas petani di Kabupaten ini menggunakan kerbau untuk membajak sawah. Kerbau yang sudah tua akan disembelih untuk dimanfaatkan dagingnya. Daging kerbau adalah sumber nutrisi potensial dengan kandungan protein yang tinggi, kandungan air rendah, dan mioglobin yang lebih tinggi daripada daging sapi Penduduk setempat di Desa Pernek selama ini telah mengolah daging kerbau menjadi dendeng citarasa tradisional, tetapi tidak pernah dikemas dengan benar. Selain itu, dendeng yang dihasilkan adalah daging yang setengah matang dengan tekstur yang cukup keras. Pemasakan dengan metode dan suhu yang tidak sesuai akan menghasilkan dendeng dengan kualitas yang rendah dan tekstur yang keras, oleh itu dendeng siap makan adalah salah satu inovasi untuk memperbaiki tekstur dan mempertahankan kandungan nutrisinya. Terdapat banyak teknik pengolahan untuk mengempukkan daging, salah satunya adalah dengan fermentasi menggunakan Bakteri Asam Laktat (BAL). Tujuan program ini adalah untuk meningkatkan nilai tambah dendeng kerbau melalui inovasi pengolahan dan pengemasan. Metode yang digunakan adalah sosialisasi, penyuluhan, serta latihan dan bimbingan. Selanjutnya, pelaksanaan acara sosialisasi berlangsung di Kantor Desa Pernek yang dihadiri oleh penduduk Desa Pernek, adapun kegiatan ini diikuti oleh pihak dari Desa seperti Badan Usaha Milik Desa (BUMDes) dan apparat desa. Melalui program ini, diharapkan masyarakat dapat meningkatkan nilai tambah dendeng kerbau olahan melalui inovasi pengolahan dan pengemasan.

Kata kunci: dendeng kerbau, Pernek, Fermentasi, Pengemasan 


\section{PENDAHULUAN}

Pembangunan pertanian saat ini diarahkan kepada pembangunan pertanian yang berorientasi agribisnis, berwawasan lingkungan dan mampu menunjang upaya pengentasan kemiskinan serta peningkatan kualitas sumberdaya manusia. Pengembangan potensi sumberdaya alam suatu kawasan mempunyai nilai strategis. Desa Pernek adalah salah satu dari 12 desa di Kecamatan Moyo Hulu, Kabupaten Sumbawa, Nusa Tenggara Barat. Penduduk Desa Pernek mayoritas berprofesi sebagai petani, dengan jenis tanaman yang dibudidayakan adalah padi dan palawija. Pertanian di Desa Pernek selama ini masih tergolong tradisional dengan memanfaatkan mesin sederhana dan tenaga hewan. Kerbau (Bubalus bubalis) banyak hidup dan berkembang biak di Pulau Sumbawa dan selama ini dimanfaatkan oleh petani untuk membajak sawah (Indriyati dan Setyorini, 2010). Apabila kerbau sudah memasuki usia tua, maka akan disembelih untuk dimanfaatkan dagingnya.

Daging kerbau memiliki tekstur yang lebih alot dan beraroma khas. Selama ini masyarakat Desa Pernek telah mengolah daging kerbau menjadi dendeng. Dendeng adalah makanan tradisional yang terbuat dari daging sapi yang diiris atau dicincang dan direndam dalam bumbu dan dikeringkan untuk memperpanjang umur simpannya. Dendeng tersebut selama ini dijual di pasar lokal, tanpa dikemas dengan baik. Selain itu tekstur dendeng yang dihasilkan juga cukup keras dan alot. Hal ini disebabkan karena masyarakat membuat dendeng setengah matang dengan dikeringkan di bawah sinar matahari pada waktu yang cukup lama. Selain itu, cara pemasakan dan suhu yang tidak tepat akan mengakibatkan dendeng berkualitas rendah dengan tekstur yang sangat keras, oleh karena itu dendeng siap makan merupakan salah satu inovasi agar dendeng lebih mudah diolah dan menjaga kandungan nutrisinya (Bower, dkk. 2006). Kurangnya inovasi pengemasan produk dan kerasnya tekstur dendeng menjadi kendala bagi masyarakat setempat dalam mengoptimalkan nilai ekonomi produk tersebut agar menjadi produk lokal unggulan. Salah satu upaya yang dapat dilakukan adalah memperkenalkan metode pengolahan yang dapat mengempukkan daging yaitu fermentasi dan inovasi pengemasan dendeng daging kerbau.

\section{METODE}

Pemberdayaan Masyarakat merupakan suatu proses bertahap yang harus dilakukan dalam rangka memperoleh dan meningkatkan daya sehingga masyarakat mampu mandiri (Winarni, 1998). Berdasarkan permasalahan yang diuraikan di atas, maka beberapa solusi yang telah dilakukan adalah sosialisasi, penyuluhan, serta pelatihan dan pendampingan pada penduduk Desa Pernek, Kecamatan Moyo Hulu. Sesuai dengan target luaran, maka dilakukan pengumpulan data dengan menggunakan metode observasi. Pelaksanaan kegiatan pengabdian kepada masyarakat ini menggunakan metode pendekatan sosial yang menempatkan masyarakat binaan sebagai subyek kegiatan dan metode kaji terap partisipatif (Participatory Action Reseach) pada tahap pelatihan penduduk desa, praktik demonstrasi pengolahan dendeng dengan metode fermentasi menggunakan starter BAL, sekaligus paking (packaging) serta pelebelan produk. Kegiatan sosialisasi, penyuluhan, pelatihan dan pendampingan dilakukan pada bulan Mei 2021, yang bertempat di Kantor Desa Pernek. 


\section{Tahap Persiapan}

Tahap persiapan ini meliputi survei awal untuk mengidentifikasi penduduk yang menjadi kelompok sasaran kegiatan, program dan metode pelatihan, serta karakteristik fisik dan sensoris dendeng yang selama ini dibuat oleh penduduk setempat.

\section{Tahap Pelaksanaan}

Adapun pelaksanaan kegiatan dilakukan dengan berbagai tahapan, meliputi:

1. Sosialisasi program kerja, dilakukan untuk menginformasikan program kerja kepada penduduk di Desa Pernek, Kecamatan Moyo Hulu.

2. Pendampingan dan pelatihan teknik pengolahan dendeng daging kerbau dengan metode fermentasi. Pada kesempatan ini, masyarakat dibina untuk dapat melakukan proses fermentasi dendeng menggunakan BAL. Telah disosialisasikan juga pemahaman proses fermentasi secara umum, faktor yang berperan dalam menunjang keberhasilan proses, dan tahapan proses pembuatan dendeng fermentasi hingga dihasilkan produk dendeng yang siap makan dan siap dikemas.

3. Pendampingan dan pelatihan teknik pengemasan dan labelling dengan pengemas Allufoil, dan diberikan pelabelan sebagai informasi produk dan meningkatkan nilai estetika bagi produk dendeng.

\section{HASIL DAN PEMBAHASAN}

Mayoritas penduduk Desa Pernek berprofesi sebagai petani padi dan palawija. Kodisi tanah yang kering dan bebatuan mengharuskan petani hanya menanam padi dan palawija maksimal 2 kali dalam setahun. Pertanian di Desa Pernek masih tergolong tradisional karena hanya memanfaatkan mesin sederhana dan tenaga hewan. Kerbau selama ini dimanfaatkan untuk membajak sawah, apabila sudah tua akan disembelih untuk dimanfaatkan dagingnya dan oleh masyarakat sekitar diolah menjadi dendeng tradisional. Citarasa dendeng tradisional yang dihasilkan adalah gurih dan asam karena hanya dibumbui dengan garam, asam jawa dan penyedap rasa. selain itu proses pengeringan dendeng menggunakan sinar matahari dan dijemur cukup lama sehingga tekstur dendeng menjadi cukup keras. Selain itu, dendeng yang dihasilkan adalah dendeng setengah matang, sehingga harus digoreng terlebih dahulu sebelum dikonsumsi. Penggorengan ini dapat mempengaruhi teksur dendeng menjadi lebih keras (Bower, dkk. 2006). Sehingga pembuatan dendeng siap makan dengan tekik fermentasi menggunakan BAL (Choi, dkk. 2008) dinilai sangat tepat untuk menghasilkan dendeng empuk dan siap dikonsumsi.

Selain itu, dendeng yang selama ini dihasilkan tidak dikemas dengan baik, melainkan hanya dikemas dalam plastik ketika ada pembeli. Penjualan dendeng dilakukan di rumahan dan pasar tradisional. Kurangnya inovasi pengemasan produk dan kerasnya tekstur dendeng menjadi kendala bagi masyarakat setempat dalam mengoptimalkan nilai ekonomi produk tersebut agar menjadi produk lokal unggulan. Salah satu upaya yang dapat dilakukan adalah memperkenalkan metode pengolahan yang dapat mengempukkan daging yaitu fermentasi dan inovasi pengemasan dendeng daging kerbau. Program pengabdian kepada masyarakat ini dilakukan dengan 
beberapa tahapan kegiatan, yaitu sosialisasi program kerja, pendampingan dan pelatihan Teknik fermentasi serta pendampingan pengemasan dan pelabelan. Program tersebut dinilai dapat meningkatkan nilai tambah olahan dendeng daging kerbau yang dihasilkan penduduk Desa Pernek, Kecamatan Moyo Hulu.

\section{Sosialisasi Program Kerja}

Pelaksanaan kegiatan sosisalisasi program kerja bertempat di Kantor Desa Pernek, dan dihadiri oleh penduduk, dan diikuti oleh pihak dari Desa seperti Badan Usaha Milik Desa (BUMDes) dan apparat desa. Materi sosialisasi diantaranya mengenai penyuluhan pengolahan daging kerbau, kewirausahaan, pengenalan metode fermentasi BAL, dan teknik pengemasan. Kegiatan ini dilakukan untuk menumbuhkan minat dan kesadaran penduduk untuk meningkatkan nilai tambah produk dendeng daging kerbau, sehingga secara otomatis dapat meningkatkan ekonomi penduduk desa. Pada kegiatan ini tampak bagwa pada dasarnya penduduk sadar ingin mengembangkan produk dendeng kerbau, tidak hanya untuk meningkatkan pendapatan namun untuk mempromosikan dendeng kerbau bercitarasa khas Sumbawa kepada pasar luar. Oleh karena itu bimbingan dan pendampingan berkelanjutan dari aparat pemerintahan desa dan instansi terkait sangat diperlukan.

\section{Pendampingan dan Pelatihan Teknik Pengolahan Dendeng dengan Metode Fermentasi}

Kegiatan ini dilakukan di Kantor Desa Pernek, dengan menggunakan alat dan bahan sederhana yang disediakan oleh tim pengabdian kepada masyarakat dari Universitas Teknologi Sumbawa. Pertama-tama daging kerbau segar diiris tipis kurang lebih $2 \mathrm{~mm}$ lalu dilakukan fermentasi di dalam wadah baskom selama 12 jam dengan konsentrasi BAL 1\%. Formulasi konsentrasi dan lama fermentasi ini merupakan kombinasi yang paling tepat untuk menghasilkan dendeng daging kerbau dengan mutu kimia dan sensoris yang terbaik, berdasarkan hasil penelitian pendahuluan dari tim pengabdian kepada masyarakat. Pengeringan dilakukan dengan menggunakan oven skala rumah tangga selama 20 menit oada suhu $130{ }^{\circ} \mathrm{C}$ (Handayani, dkk., 2015), hingga dihasilkan dendeng yang siap makan (ready-to-eai).
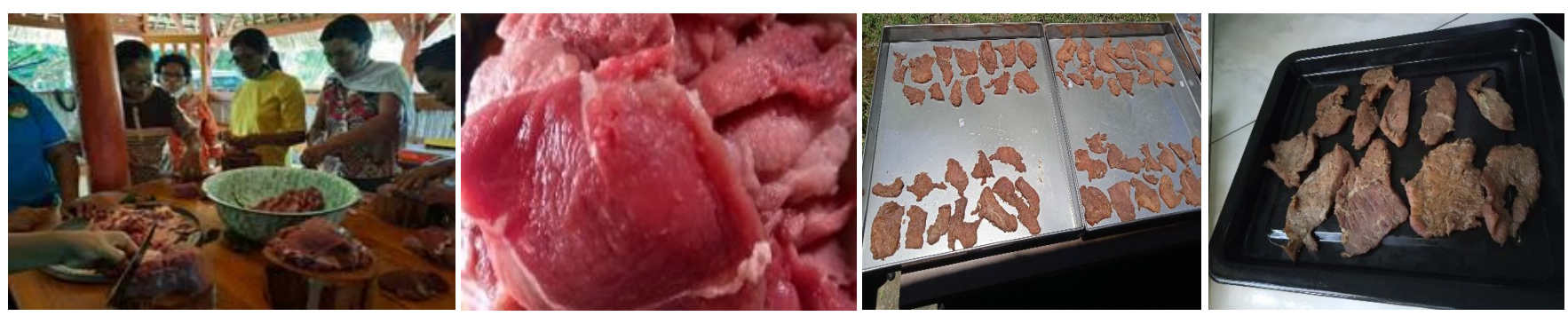

Gambar 1.

Pendampingan Teknik Pengolahan Dendeng 


\section{Pendampingan dan Pelatihan Teknik Pengolahan Dendeng dengan Metode Fermentasi.}

Kegiatan ini dilakukan di Kantor Desa Pernek, dan dilakukan pendampingan pengemasan dendeng menggunakan standing pouch Allufoil, secara aseptis. Selain itu, dilakukan juga pelatihan pemberian pelabellan pada kemasan, sehingga produk yang dihasilkan terlindungi dari lingkungan luar dan memiliki nilai estetika. Desain kemasan dibantu oleh tim pengabdian kepada masarakat yang meliputi pemberian penamaan produk yang menarik, pemberian komposisi bahan, dan pemberian gambar yang eye -catching.
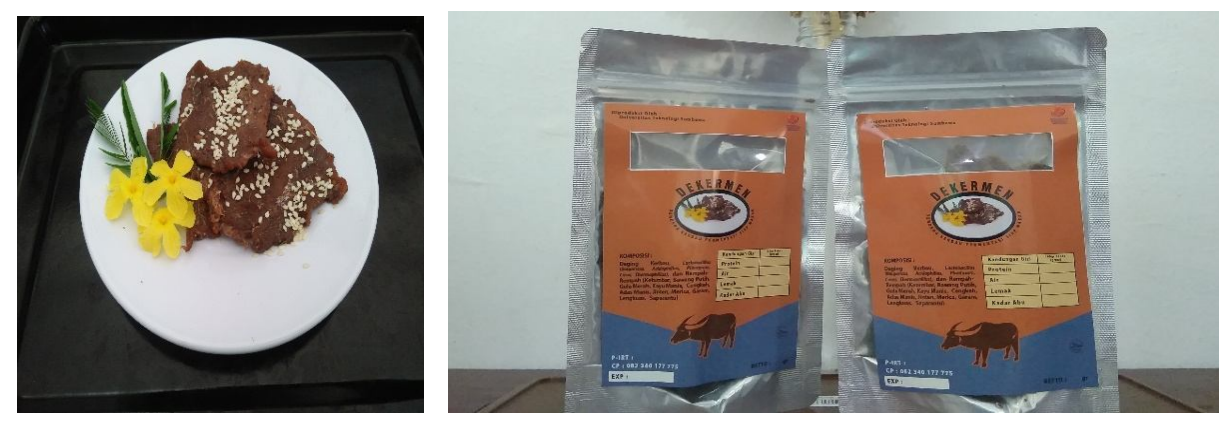

Gambar 2.

Pengemasan dendeng fermentasi

\section{KESIMPULAN DAN SARAN}

Upaya peningkatan nilai tambah produk dendeng kerbau dilakukan melalui pemberdayaan masyarakat yang disertai penyuluhan mengenai proses pengolahan bahan baku, proses fermentasi, teknik kewirausahaan, serta teknik pengemasan dan pelabelan produk dendeng siap makan. Luaran dari kegiatan ini telah dihasilkan dendeng fermentasi siap makan dengan citarasa dan tekstur yang baik, serta dikemas secara aseptis sehingga lebih menarik minat pembeli. Diharapkan kegiatan ini dapat meningkatkan pendapatan penduduk Desa Pernek dalam penjualan dendeng daging kerbau.

\section{Ucapan Terima Kasih}

Penulis mengucapkan terima kasih kepada Universitas Teknologi Sumbawa karena telah mendanai penelitian dan pengabdian ini melalui program pendanaan Hibah Internal UTS tahun 2020. Selain itu terima kasih juga disampaikan kepada segenap aparat Desa Pernek dan mahasiswa Fakultas Teknoologi Pertanian Universitas Teknologi Sumbawa yang telah membantu terlaksananya program ini. 


\section{Daftar Pustaka}

Bower, C. K., Schilke, K. F., and M A Daeschel. 2006. Antimicrobial Properties of Raisins in Beef Jerky Preservation. Journal of Food Science. DOI: https://doi.org/10.1111/j.1365-2621.2003.tb09671.x

Choi, J. H Jeong, J. Y. Han, D. J. Choi, Y. S. Kim H, Y, M A Lee, E S Lee, H D Paik, and C J Kim. 2008. Effect of Pork. Beef Levels and Various Casings on Quality Properties of Semi-Dried Jerky. Journal of Meat Science. DOI: https://doi.org/10.1016/j.meatsci.2007.11.028

Handayani, BR. Margana, C.C.E Kertanegara, A Hidayati and W Werdiningsih. 2015. The Study of Marination Time on the Quality of Traditional Dried Meat Ready to Eat. Teknol. dan Industri Pangan.26 (1), 17-25.

Indriyati dan Setyorini, A. 2010. Isolasi dan Karakterisasi Bakteri Asam Laktat (dari Susu Formula Balita yang Berpotensi Menghasilkan Substansi Antimikroba. SKRIPSI. Yogyakarta: Universitas Islam Negeri Sunan Kalijaga. 